\title{
Aplikasi Multimedia sebagai Media Pembelajaran Sejarah Indonesia Masa Perjuangan Kemerdekaan Untuk Sekolah Dasar Berbasis Android
}

\author{
Aulia Nastiti ${ }^{1)}$, R. Rizal Isnanto ${ }^{2)}$, Kurniawan Teguh Martono ${ }^{2)}$ \\ Program Studi Sistem Komputer Fakultas Teknik Universitas Diponegoro \\ Jalan Prof. Sudharto, Tembalang, Semarang, Indonesia \\ nastitiaulia@gmail.com
}

\begin{abstract}
History teaching at school needs new methods to improve students' interest in learning history. This is because method that commonly used in schools is where students only listen to what teacher explained. The textbooks used usually only have few illustrations so that students are less interested and easily bored. Based on this problem, A Multimedia Learning Application was built and it is specifically made for Android devices. This application is expected to support the learning process at school. It was built using the Unity Engine. Adobe Illustrator and Adobe Photohop also used to create application's design and illustrations to improve application's interface. Development method used for this application is the Multimedia Development Life Cycle (MDLC). This application was tested using the Black Box Test and the Beta Test. Results from Black Box testing is that all functions in this application has been running properly. Results obtained from Beta testing is that more than $75 \%$ of respondents gave positive responses to the application and it can be concluded that Multimedia Learning Application can be used to support the learning process at school.

Keywords: Multimedia Learning, Unity Engine, Multimedia Development Life Cycle (MDLC), History of Indonesia.
\end{abstract}

\section{PENDAHULUAN}

Sejarah merupakan bagian penting dalam kehidupan bangsa suatu negara. Walau sejarah adalah kejadian masa lalu yang telah terjadi, namun perjuangan para pahlawan di masa lampau dalam memperjuangkan kemerdekaan sudah seharusnya diketahui masyarakat sebagai pembelajaran dan diharapkan dapat meneruskan semangat para pejuang dan memanfaatkan hasil yang didapat, yaitu, kemerdekaan. Pelajaran sejarah telah diberikan sebagai mata pelajaran wajib sejak sekolah dasar yang dirangkum dalam mata pelajara Ilmu Pengetahuan Sosial atau IPS.

Namun pada kenyataannya, dalam proses pembelajaran sejarah, hanya terpaut pada buku teks dan ditambah juga dengan metode pembelajaran yang kaku. Siswa hanya menghapal untuk sementara bukan untuk jangka panjang. Hal ini dapat menjadi penyebab awal dari generasi yang melupakan sejarah bangsanya sendiri.

Maka dari itu salah satu solusi yang dapat dilakukan untuk mewujudkan pembelajaran sejarah yang menyenangkan dan tidak kaku adalah dengan memanfaatkan teknologi. Hal ini juga didukung dengan semakin banyaknya masyarakat yang telah memiliki dan menggunakan perangkat bergerak (mobile device). Melalui penelitian ini, penulis bermaksud membuat sebuah game bertema edukasi yang bertujuan untuk mendukung proses pembelajaran sejarah. Pada aplikasi multimedia ini akan diselipkan informasiinformasi sejarah khususnya sejarah perjuangan kemerdekaan
Indonesia dengan acuan buku teks Ilmu Pengetahuan Sosial (IPS) kelas 5 SD.

Berdasarkan latar belakang di atas, maka permasalahan yang diangkat dalam Tugas Akhir ini yaitu:

"Bagaimana merancang dan membuat aplikasi yang dapat mendukung pembelajaran sejarah khususnya sejarah perjuangan kemerdekaan Indonesia untuk Sekolah Dasar?"

"Dapatkah media pembelajaran interaktif direkomendasikan sebagai pendukung pembelajaran sejarah untuk Sekolah Dasar?"

Berdasarkan latar belakang masalah tersebut dapat dibuat suatu rumusan masalah, yaitu:

a. Bagaimana merancang dan membuat aplikasi yang dapat mendukung pembelajaran sejarah khususnya sejarah perjuangan kemerdekaan Indonesia untuk Sekolah Dasar?

b. Dapatkah media pembelajaran interaktif direkomendasikan sebagai pendukung pembelajaran sejarah untuk Sekolah Dasar?

\section{LANDASAN TEORI}

\section{A. Media Pembelajaran}

Media pendidikan memegang peranan yang penting dalam proses pembelajaran. Penggunaan media pendidikan, dapat membantu guru dalam menyapaikan materi pembelajaran. Keberhasilan pembelajaran sangat ditentukan oleh dua komponen utama yaitu metode mengajar dan media pembelajaran. Kedua komponen ini salin berkaitan dan tidak bisa dipisahkan. ${ }^{[1]}$

Pemakaian media pembelajaran dalam proses belajar mengajar dapat membangkitkan keinginan dan minat yang baru dan membangkitkan motivasi dan rangsangan kegiatan belajar, dan bahkan membawa pengaruh-pengaruh psikologis terhadap siswa. Penggunaan media pembelajaran pada tahap orientasi pembelajaran akan sangat membantu keefektifan proses pembelajaran dan penyampaian pesan dan isi pelajaran pada saat itu. Selain membangkitkan motivasi dan minat siswa, media pembelajaran juga dapat membantu siswa meningkatkan pemahaman, menyajikan data dengan menarik dan terpercaya, memudahkan penafsiran data, dan memadatkan informasi. ${ }^{[2]}$

\section{B. Multimedia}

Multimedia merujuk pada presentasi materi dengan menggunakan kata-kata dan gambar-gambar. Multimedia dapat dikatakan suatu bentuk baru dalam pembuatan program-program komputer dengan penggambungan lebih 
dari suatu media. Meskipun hanya mengandung sedikitnya dua elemen, sudah dikatakan sebagai multimedia. Pengertian multimedia menurut Rosch: "Multimedia adalah kombinasi dari komputer dan video"; adapun pengertian menurut McCornick: "Multimedia secara umum merupakan kombinasi tiga elemen, yaitu suara, gambar dan teks".

Menurut Turban dkk: "Multimedia adalah kombinasi dari paling sedikit dua media input atau output dari data, media ini dapat audio (suara, musik), animasi, video, teks, grafik dan gambar". Menurut Robin dan Linda: "Multimedia merupakan alat yang dapat menciptakan presentasi yang dinamis dan interaktif yang mengkombinasikan teks, grafik, animasi, audio, dan gambar video." [3]

\section{Multimedia Pembelajaran Interaktif}

Multimedia dapat digunakan sebagai pembelajaran interaktif karena learner (alias murid, yakni orang yang sedang belajar) lebih bisa memahami penjelasan jika disampaikan dengan kata-kata dan gambar-gambar daripada jika disajikan hanya dalam kata-kata.

Proses multimedia learning bisa dipandang sebagai akuisisi informasi (pesan-pesan multimedia adalah kendaraan pengirim informasi), atau sebagai instruksi pengetahuan (pesan-pesan multimedia adalah alat bantu untuk menciptakan penalaran). ${ }^{[4]}$

Pada dasarnya salah satu tujuan pembelajaran dengan multimedia interaktif adalah sedapat mungkin menggantikan dan atau melengkapi serta mendukung unsur-unsur: tujuan, materi, metode, dan alat penilaian yang ada dalam proses belajar mengajar dalam sistem pendidikan konvensional yang biasa kita lakukan. ${ }^{[5]}$

\section{Unity Engine}

Unity Engine suatu game engine yang terus berkembang.Engine ini merupakan salah satu game enginedengan lisensi source proprietary, namun untuk lisensi pengembangan dibagi menjadi 2, yaitu free (gratis) dan berbayar sesuai perangkat target pengembangan aplikasi.

Seperti kebanyakan game engine lainnya, Unity Engine dapat mengolah beberapa data seperti objek tiga dimensi, suara, teksture, dan lain sebagainya. Keunggulan dari unity engine ini dapat menangani grafik dua dimensi dan tiga dimensi.Namun engine ini lebih konsentrasi pada pembuatan grafik tiga dimensi. . Dari beberapa game engine yang samasama menangani grafik tiga dimensi, Unity Engine dapat menangani lebih banyak. Beberapa diantaranya yaitu Windows, MacOS X, iOS, PS3, wii, Xbox 360, dan Android.

Unity Engine memiliki kerangka kerja (framework) lengkap untuk pengembangan profesional. Sistem inti engine ini menggunakan beberapa pilihan bahasa pemrogramam, diantaranya $\mathrm{C \#}$, javascript maupun boo. ${ }^{[6]}$

\section{E. Metodologi Pengembangan Mutimedia}

Metodologi yang digunakan adalah Multimedia Development Life Cycle (MDLC) yang bersumber dari Luther dan sudah dimodifikasi oleh Sutopo. Metodologi pengembangan multimedia tersebut terdiri dari enam tahap, yaitu konsep (concept), desain (design), pengumpulan materi (material collecting), pembuatan (assembly), pengujian (testing), dan distribusi (distribution). Keenam tahap ini tidak harus berurutan dalam prakteknya, tahap-tahap tersebut dapat saling bertukar posisi. Meskipun begitu, tahap konsep memang harus menjadi hal yang pertama kali dikerjakan. ${ }^{[7]}$ Tahapan pengembangan multimedia ditunjukkan oleh Gambar 1.

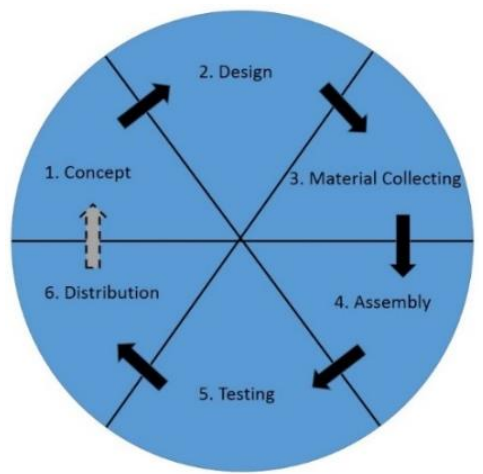

Gambar 1. Tahapan pengembangan multimedia

F. Metode Pengumpulan Data

Menurut Arikunto: "Angket / kuisioner adalah kumpulan dari pertanyaan yang diajukan secara tertulis dan digunakan untuk memperoleh informasi dari responden."

Dalam penelitian ini menggunakan skala likert. Skala likert adalah suatu skala psikometrik yang umum digunakan dalam kuisioner, dan merupakan skala paling banyak digunakan dalam riset berupa survei. Untuk menanggapi pertanyaan dalam skala likert, responden menentukan tingkat persetujuan mereka terhadap suatu pertanyaan dengan memilih salah satu dari pilihan yang tersedia. Metode pengujian aplikasi yang digunakan adalah metode Black Box Test dan Alpha Test. ${ }^{[8]}$

\section{PERANCANGAN SISTEM}

\section{A. Konsep}

Secara garis besar, konsep dari pembuatan aplikasi dideskripsikan pada Tabel 1.

Tabel 1 Tabel deskripsi konsep aplikasi

\begin{tabular}{|l|c|l|}
\hline \multirow{2}{*}{ Judul } & $:$ & $\begin{array}{l}\text { Aplikasi Multimedia sebagai Media } \\
\text { Pembelajaran Ilmu Pengetahuan Sosial } \\
\text { Materi Sejarah Masa Perjuangan } \\
\text { Kemerdekaan Indonesia berbasis } \\
\text { Android }\end{array}$ \\
\hline Pengguna & $:$ & Siswa Sekolah Dasar \\
\hline Jenis & $:$ & Pendidikan \\
\hline Durasi & $:$ & Tidak ada \\
\hline & $:$ & $\begin{array}{l}\text { Menggunakan foto sebagai ilustrasi } \\
\text { materi yang didapat dari hasil pencarian } \\
\text { Image }\end{array}$ \\
& & $\begin{array}{l}\text { internet. Gambar lainnya dibuat } \\
\text { Adobe Photoshop CS5 }\end{array}$ \\
\hline Audio & $:$ & $\begin{array}{l}\text { Latar belakang musik diaransemen oleh } \\
\text { Wesley Krauss yang diambil dari } \\
\text { internet. Suara efek didapat dari hasil }\end{array}$ \\
\hline
\end{tabular}




\begin{tabular}{|l|c|l|}
\hline & & pencarian di internet. \\
\hline Video & $:$ & Tidak menggunakan \\
\hline Animasi & $:$ & $\begin{array}{l}\text { Animasi dibentuk menggunakan fitur } \\
\text { Animation dari Unity versi 5.0 }\end{array}$ \\
\hline Nilai & $:$ & $\begin{array}{l}\text { Tahap Telusuri merupakan tahap } \\
\text { menampilkan materi sejarah. Terdapat 2 } \\
\text { bentuk yaitu bentuk peta dan daftar isi. } \\
\text { Tahap Latihan menampilkan pertanyaan } \\
\text { tentang sejarah berdasarkan materi yang } \\
\text { ada kemudian memilih jawaban untuk } \\
\text { mendapatkan nilai. }\end{array}$ \\
\hline $\begin{array}{l}\text { Ukuran } \\
\text { Aplikasi }\end{array}$ & $:$ & $50 \mathrm{MB}$ \\
\hline
\end{tabular}

\section{B. Perancangan}

Use case diagram digunakan untuk memodelkan dan menyatakan unit fungsi atau layanan yang disediakan oleh sistem ke pengguna. Dalam aplikasi Pembelajaran Sejarah hanya ada satu pengguna yaitu user. User dapat berinteraksi dan dapat melakukan tindakan ke dalam sistem yang sudah memiliki skenario didalamnya. Berikut adalah use case diagram dari Aplikasi Pembelajaran Sejarah yang telah ditunjukkan pada Gambar 2

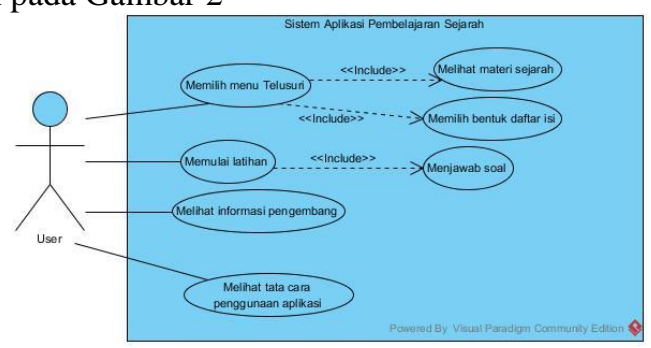

Gambar 2. Use case diagram Aplikasi Pembelajaran Sejarah

Deskripsi atau penjelasan dari masing-masing use case diatas dapat dilihat pada Tabel 2.

Tabel 2 Tabel Deskripsi Use Case Diagram

\begin{tabular}{|c|l|l|}
\hline No & Use Case & Deskripsi \\
\hline 1 & $\begin{array}{l}\text { Memilih menu } \\
\text { Telusuri }\end{array}$ & $\begin{array}{l}\text { Proses ketika pengguna memilih } \\
\text { menu Telusuri pada aplikasi }\end{array}$ \\
\hline 2 & $\begin{array}{l}\text { Melihat materi } \\
\text { sejarah }\end{array}$ & $\begin{array}{l}\text { Proses pengguna melihat materi } \\
\text { sejarah yang terdapat di dalam } \\
\text { aplikasi }\end{array}$ \\
\hline 3 & $\begin{array}{l}\text { Melihat bentuk } \\
\text { daftar isi }\end{array}$ & $\begin{array}{l}\text { Proses pengguna memilih } \\
\text { tampilan urutan materi dalam } \\
\text { bentuk daftar isi }\end{array}$ \\
\hline 4 & Memulai latihan & $\begin{array}{l}\text { Proses ketika pengguna memilih } \\
\text { menu Yuk Latihan dan } \\
\text { menampilkan pertanyaan dan } \\
\text { pilihan jawaban }\end{array}$ \\
\hline 5 & Menjawab soal & $\begin{array}{l}\text { Proses ketika pengguna memilih } \\
\text { jawaban dari pertanyaan yang } \\
\text { telah tersedia }\end{array}$ \\
\hline 7 & $\begin{array}{l}\text { Melihat informasi } \\
\text { pengembang }\end{array}$ & $\begin{array}{l}\text { Proses ketika pengguna ingin } \\
\text { menampilkan informasi } \\
\text { mengenai pengembang aplikasi }\end{array}$ \\
\hline & $\begin{array}{l}\text { penggunaan } \\
\text { aplikasi }\end{array}$ & $\begin{array}{l}\text { Proses ketika pengguna } \\
\text { membutuhkan bantuan dalam } \\
\text { menggunakan aplikasi }\end{array}$ \\
\hline
\end{tabular}

Sequence diagram digunakan untuk menggambarkan interaksi antar objek di dalam dan di sekitar sistem yang berupa pesan yang digambarkan terhadap waktu. Sequence diagram terdiri antara dimensi vertikal (waktu) dan dimensi horizontal (objek-objek yang terkait). Berikut adalah sequence diagram dari diagram use case yang digunakan pada Aplikasi Pembelajaran Sejarah.

1. Sequence diagram memilih menu Telusuri

Berikut adalah sequence diagram memilih menu Telusuri yang ditunjukkan oleh Gambar 3 .

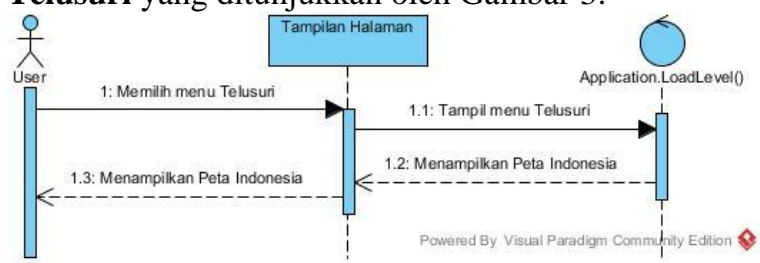

Gambar 3. Sequence diagram memilih menu Telusuri

2. Sequence diagram melihat materi sejarah

Berikut adalah sequence diagram melihat materi sejarah yang ditunjukkan oleh Gambar 4.

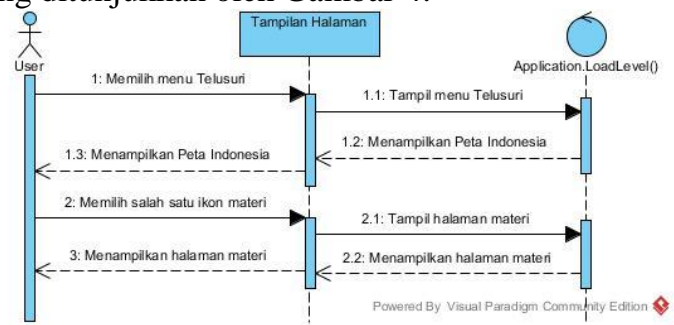

Gambar 4. Sequence diagram melihat materi sejarah

3. Sequence diagram melihat bentuk daftar isi

Berikut adalah sequence diagram melihat urutan materi sejarah dalam bentuk daftar isi yang ditunjukkan oleh Gambar 5.

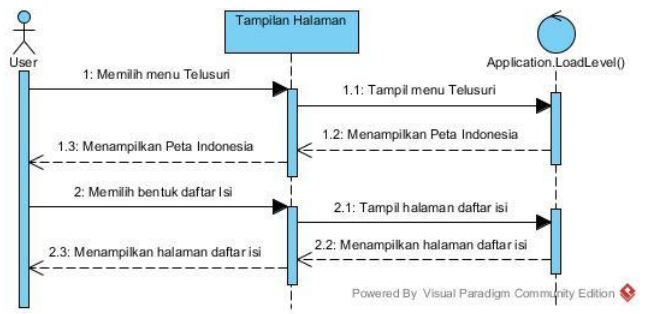

Gambar 5. Sequence diagram melihat materi sejarah

4. Sequence diagram memilih menu Yuk Latihan Berikut adalah sequence diagram memilih menu latihan yang ditunjukkan oleh Gambar 6.

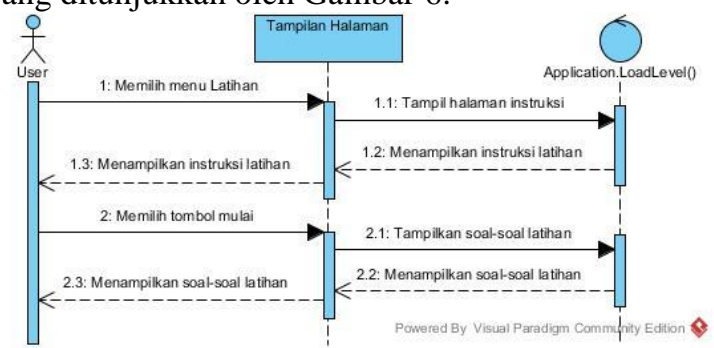

Gambar 6. Sequence diagram memilih menu latihan 
5. Sequence diagram menjawab soal latihan

Berikut adalah sequence diagram menjawab soal pada latihan yang ditunjukkan oleh Gambar 7.

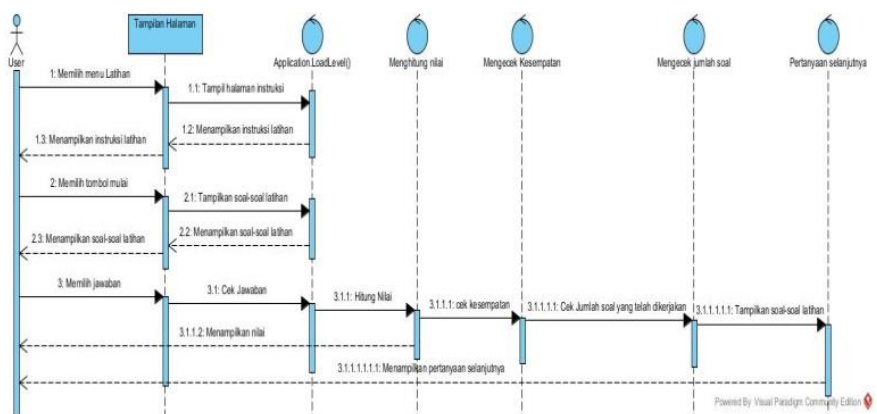

Gambar 7. Sequence diagram menjawab soal

6. Sequence diagram melihat informasi pengembang Berikut adalah sequence diagram melihat informasi pengembang yang ditunjukkan oleh Gambar 8 .

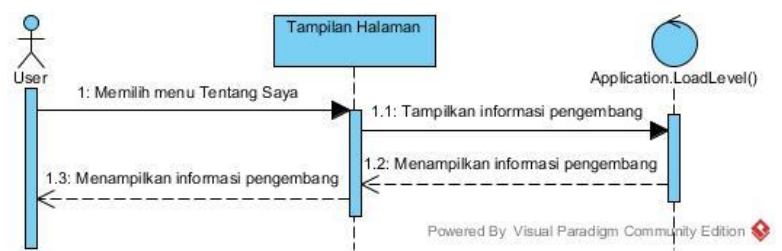

Gambar 8. Sequence diagram melihat informasi pengembang

7. Sequence diagram melihat tata cara penggunaan aplikasi Berikut adalah sequence diagram melihat tata cara penggunaan aplikasi ditunjukkan oleh Gambar 9.

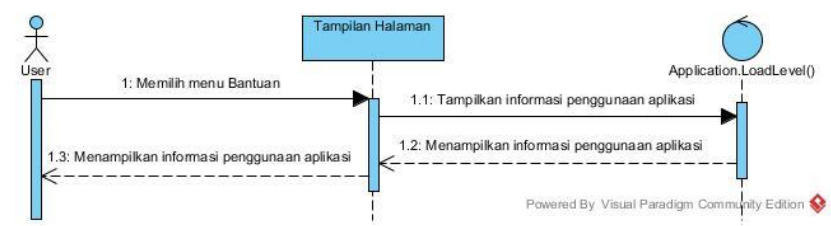

Gambar 9. Sequence diagram melihat tata cara menggunakan aplikasi

Berikut adalah skenario jalannya masing-masing use case yang telah didefinisikan sebelumnya dan digambarkan melalui sequence diagram :

1. Skenario memilih menu Telusuri

Skenario memilih menu Telusuri ditunjukkan pada

Tabel 3

Tabel 3 Skenario use case memilih menu Telusuri

\begin{tabular}{|l|l|l|}
\hline $\begin{array}{l}\text { Nama use } \\
\text { case }\end{array}$ & \multicolumn{2}{|l|}{ Memilih Menu Telusuri } \\
\hline Aktor & User & \multicolumn{2}{|l|}{ Reaksi Sistem } \\
\hline & Aksi Aktor & \\
\hline \multirow{2}{*}{$\begin{array}{c}\text { Skenario } \\
\text { Normal }\end{array}$} & $\begin{array}{l}\text { Memilih tombol } \\
\text { Telusuri pada } \\
\text { menu halaman } \\
\text { utama. }\end{array}$ & \\
\cline { 2 - 3 } & & $\begin{array}{l}\text { 2. } \\
\text { Menerima } \\
\text { permintaan dari }\end{array}$ \\
\hline
\end{tabular}

\begin{tabular}{|l|l|l|}
\hline & user, lalu \\
& menampilkan \\
halaman Menu \\
Telusuri yaitu \\
& peta Indonesia \\
& dengan ikon \\
& yang mewakili \\
& materi sejarah \\
\hline
\end{tabular}

2. Skenario melihat materi sejarah

Skenario melihat materi sejarah tiap provinsi ditunjukkan pada Tabel 4

Tabel 4 Skenario use case melihat materi sejarah

\begin{tabular}{|c|c|c|}
\hline Nama use & \multicolumn{2}{|c|}{ Melihat materi sejarah } \\
\hline Aktor & \multicolumn{2}{|l|}{ User } \\
\hline & Aksi Aktor & Reaksi Sistem \\
\hline \multirow[b]{2}{*}{$\begin{array}{c}\text { Skenario } \\
\text { Normal }\end{array}$} & $\begin{array}{l}\text { 1. Memilih salah } \\
\text { satu ikon yang } \\
\text { terdapat pada } \\
\text { peta. }\end{array}$ & \\
\hline & & $\begin{array}{ll}2 . & \text { Menerima } \\
\text { permintaan dari } \\
\text { user, lalu } \\
\text { menampilkan } \\
\text { halaman materi } \\
\text { sejarah }\end{array}$ \\
\hline
\end{tabular}

3. Skenario melihat urutan materi dalam bentuk daftar isi Skenario melihat urutan materi dalam bentuk daftar isi ditunjukkan pada Tabel 5

Tabel 5 Skenario use case melihat bentuk daftar isi

\begin{tabular}{|c|c|c|}
\hline \multirow{3}{*}{$\begin{array}{l}\begin{array}{l}\text { Nama use } \\
\text { case }\end{array} \\
\text { Aktor } \\
\end{array}$} & \multicolumn{2}{|c|}{ Melihat bentuk daftar isi } \\
\hline & User & \\
\hline & Aksi Aktor & Reaksi Sistem \\
\hline \multirow[b]{2}{*}{$\begin{array}{c}\text { Skenario } \\
\text { Normal }\end{array}$} & $\begin{array}{l}\text { 1. Memilih ikon } \\
\text { daftar isi pada } \\
\text { halaman peta }\end{array}$ & \\
\hline & & 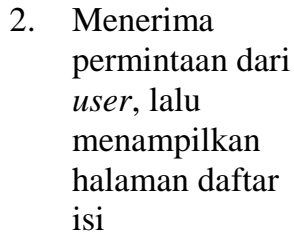 \\
\hline
\end{tabular}

4. Skenario memilih menu Yuk Latihan

Skenario memilih menu Yuk Latihan ditunjukkan pada Tabel 6

Tabel 6 Skenario use case memilih menu Yuk Latihan (latihan)

\begin{tabular}{|c|c|c|}
\hline Nama use & \multicolumn{2}{|c|}{ Memilih menu Yuk Latihan } \\
\hline \multirow{2}{*}{ Aktor } & \multicolumn{2}{|l|}{ User } \\
\hline & Aksi Aktor & Reaksi Sistem \\
\hline \multirow{2}{*}{$\begin{array}{l}\text { Skenario } \\
\text { Normal }\end{array}$} & $\begin{array}{ll}1 & \begin{array}{l}\text { Memilih tombol } \\
\text { Yuk Latihan }\end{array} \\
\end{array}$ & \\
\hline & & 2 Menerima \\
\hline
\end{tabular}


permintaan dari user, lalu menampilkan halaman latihan yang berisi pertanyaan dan pilihan jawaban

5. Skenario menjawab soal

Skenario menjawab soal pada latihan ditunjukkan pada Tabel 7

Tabel 7 Skenario use case menjawab soal

\begin{tabular}{|c|c|c|c|}
\hline Nama use & Menjawab soal & & \\
\hline Aktor & \multicolumn{3}{|l|}{ User } \\
\hline \multirow{8}{*}{$\begin{array}{c}\text { Skenario } \\
\text { Normal }\end{array}$} & Aksi Aktor & \multicolumn{2}{|r|}{ Reaksi Sistem } \\
\hline & $1 \quad \begin{array}{l}\text { Memilih } \\
\text { jawaban }\end{array}$ & & \\
\hline & & & $\begin{array}{l}\text { Menerima } \\
\text { permintaan dari } \\
\text { user, lalu } \\
\text { menampilkan } \\
\text { hasil jawaban } \\
\text { (benar/salah) }\end{array}$ \\
\hline & & & $\begin{array}{l}\text { Menambah nilai } \\
\text { apabila pilihan } \\
\text { jawaban benar }\end{array}$ \\
\hline & & & $\begin{array}{l}\text { Mengurangi } \\
\text { jumlah } \\
\text { kesempatan bila } \\
\text { salah }\end{array}$ \\
\hline & & & $\begin{array}{l}\text { Kesempatan } \\
\text { habis, latihan } \\
\text { berakhir }\end{array}$ \\
\hline & & & $\begin{array}{l}\text { Menghitung } \\
\text { jumlah soal yang } \\
\text { telah dikerjakan }\end{array}$ \\
\hline & & & $\begin{array}{l}\text { Menampilkan } \\
\text { hasil } \\
\text { perhitungan nilai }\end{array}$ \\
\hline
\end{tabular}

8 Skenario melihat menu Tentang Saya

Skenario memilih menu Tentang Saya ditunjukkan pada Tabel 8

Tabel 8 Skenario use case melihat menu Tentang Saya

\begin{tabular}{|c|c|c|}
\hline Nama use & \multicolumn{2}{|c|}{ Melihat menu Tentang Saya } \\
\hline \multirow[t]{2}{*}{ Aktor } & \multicolumn{2}{|l|}{ User } \\
\hline & Aksi Aktor & Reaksi Sistem \\
\hline \multirow[b]{2}{*}{$\begin{array}{c}\text { Skenario } \\
\text { Normal }\end{array}$} & $\begin{array}{ll}1 & \text { Memilih tombol } \\
\text { Tentang Saya }\end{array}$ & \\
\hline & & $\begin{array}{ll} & \text { Menerima } \\
\text { permintaan dari } \\
\text { user, lalu } \\
\text { menampilkan } \\
\text { halaman yang } \\
\text { berisi informasi }\end{array}$ \\
\hline
\end{tabular}

\begin{tabular}{|l|l|l|}
\hline & & $\begin{array}{l}\text { pengembang } \\
\text { aplikasi }\end{array}$ \\
\hline
\end{tabular}

3 Skenario melihat menu Bantuan

Skenario memilih menu Bantuan ditunjukkan pada Tabel 9

Tabel 9 Skenario use case melihat menu Bantuan

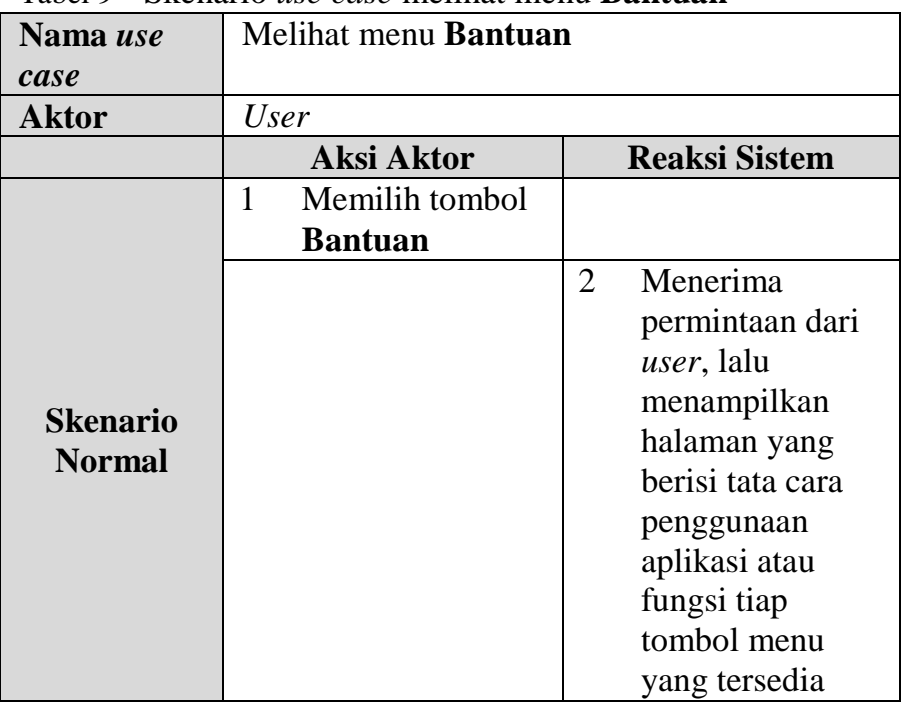

Tahap perancangan berupa diagram alir atau flowchart digunakan untuk perancangan fungsi perhitungan nilai pada latihan. Diagram alir atau flowchart untuk fungsi perhitungan nilai, ditunjukkan pada Gambar 10.

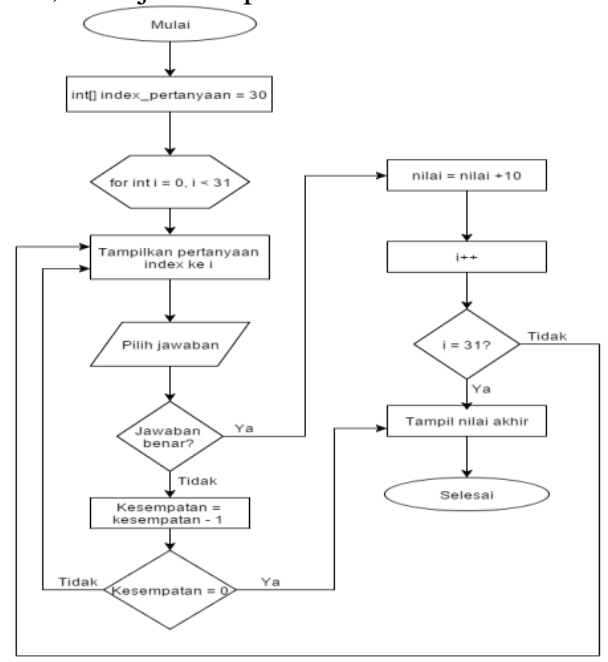

Gambar 10.Diagram alir fungsi perhitungan nilai latihan

Setelah dibuat diagram alir untuk mengetahui alur program, selanjutnya dibuat desain tampilan aplikasi. Tampilan menu awal ditunjukkan oleh Gambar 11.

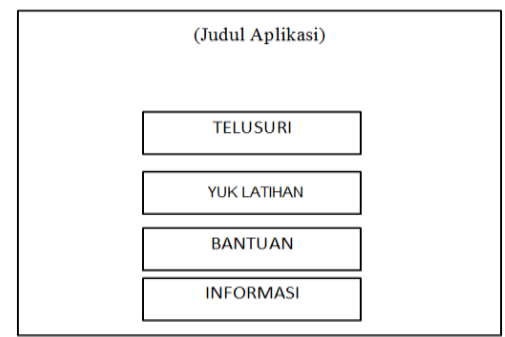


Gambar 11.Tampilan menu awal

Tampilan menu Telusuri ditunjukkan oleh Gambar 1213.

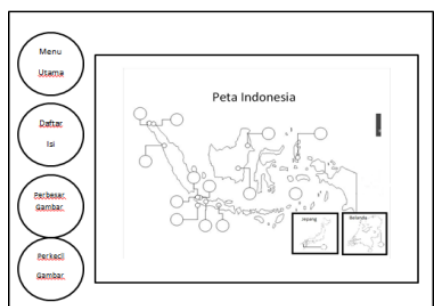

Gambar 12.Tampilan menu Telusuri (Peta)

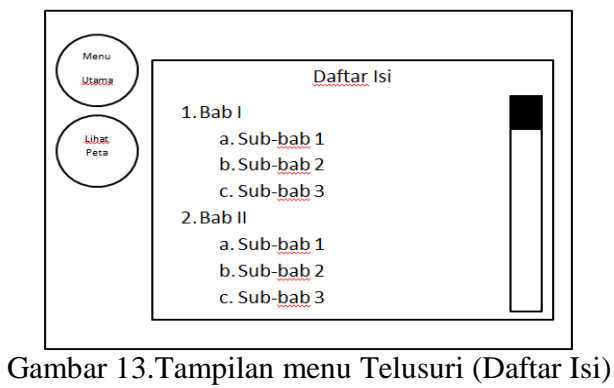

Tampilan menu materi ditunjukkan oleh Gambar 14.

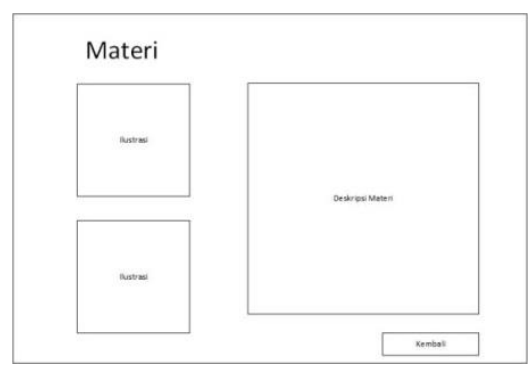

Gambar 14.Tampilan menu materi

Tampilan menu Yuk Latihan ditunjukkan oleh Gambar 15-17.

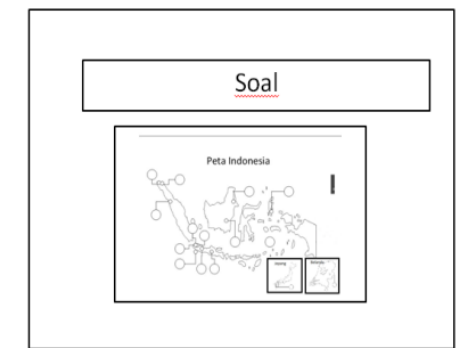

Gambar 15.Tampilan menu latihan (1)

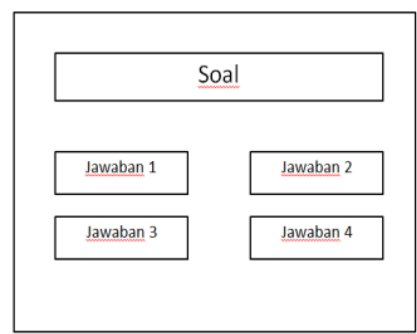

Gambar 16.Tampilan menu latihan (2)

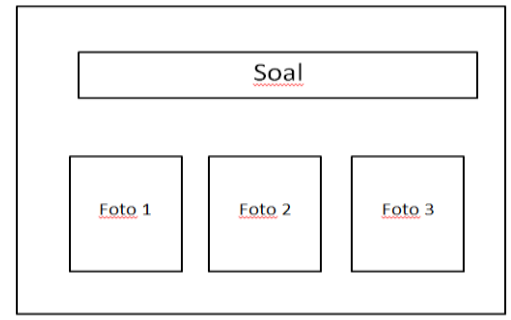

Gambar 17.Tampilan menu latihan (3)

Tampilan menu Bantuan ditunjukkan oleh Gambar 18.

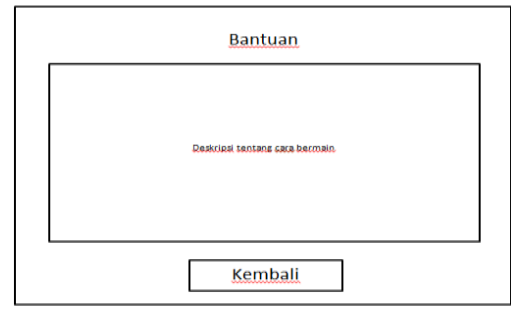

Gambar 18.Tampilan menu Bantuan

Tampilan menu Tentang Saya ditunjukkan oleh Gambar 19.

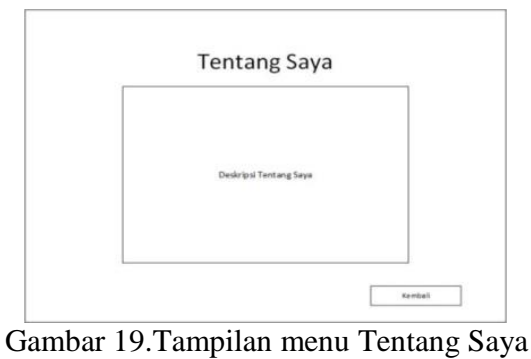

C. Pengumpulan Materi

Berikut rangkuman materi sejarah masa perjuangan kemerdekaan yang diambil dari buku Ilmu Pengetahuan Sosial kelas 5 SD.

1. Masa Penjajahan Belanda

Tahun 1956 bangsa Belanda di bawah pemimpin Cornelis de Houtman berlabuh di Banten. Mereka datang untuk berdagang rempah-rempah di antaranya di Kepulauan Maluku. Akan tetapi, mereka harus menghadapi persaingan yang berat, yaitu dari pedagang Islam dan pedagang Eropa lainnya. Sehubungan dengan hal itu Belanda mendirikan Vereenigde Oost Indische Compagnie (VOC), artinya kongsi dagang Belanda di Hindia Timur. VOC memaksakan sistem monopoli. Di masa ini rakyat dipaksa bekerja untuk VOC dan diwajibkan membayar pajak dengan jumlah yang ditentukan oleh VOC.

2. Masa Penjajahan Jepang

Tanggal 8 Desember 1941 Perang Pasifik atau Perang Asia Timur Raya pecah. Jepang menyerang Hawai, Amerika Serikat. Selanjutnya, Jepang menyerbu ke Asia Timur dan Asia Tenggara. Indonesia dikuasai Jepang pada tahun 1942. Pemerintah Belanda yang sudah lemah dengan mudah dihancurkan oleh pasukan Jepang. Akhirnya Jepang berkuasa di Indonesia. Harapan rakyat Indonesia, Jepang lebih baik dari Belanda. Kedatangan Jepang semula diangap sebagai 
pembebas rakyat dari penindasan Belanda. Namun pada kenyataannya, selama masa pendudukan Jepang, rakyat Indonesia sangat menderita. Ternyata Jepang dan Belanda tidak jauh berbeda.

\section{Organisasi Pergerakan Nasional}

Terdapat berbagai organisasi pergerakan nasional yang didirikan oleh pemuda Indonesia yang bertujuan untuk mewujudkan kemerdekaan Indonesia dan melindungi rakyat dari penderitaan penjajahan. Di antaranya adalah Budi Utomo, Serikat Dagang Islam, Indische Partij, dan Perhimpunan Indonesia.

4. Proklamasi

Menyerahnya Jepang kepada Sekutu pada Perang Dunia II membangkitkan semangat bangsa Indonesia untuk segera memproklamasikan kemerdekaan. Setelah melalui berbagai peristiwa, akhirnya bangsa Indonesia memproklamasikan kemerdekaan pada tanggal 17 Agustus 1945.

\section{Pembuatan}

Alat dan bahan yang digunakan dalam pembuatan multimedia pembelajaran ini adalah sebagai berikut.

a. Perangkat keras

- PC (Personal Computer) atau Laptop

- Angket (Kuisioner)

b. Perangkat lunak

- Microsoft Windows 8

- Unity Engine 5.0

- Adobe Illustrator

- Adobe Photoshop

\section{HASIL PENELITIAN DAN PEMBAHASAN}

A. Hasil pembuatan aplikasi pembelajatan IPS materi Perjuangan Kemerdekaan untuk SD

Berikut merupakan tampilan aplikasi yang dibuat.

\section{Menu Utama}

. Pada halaman utama aplikasi terdapat 4 tombol utama yang masing-masing memiliki fungsi berbeda. Tombol Telusuri untuk masuk ke bagian inti aplikasi, tombol Latihan untuk masuk ke menu yang berisi soal-soal, tombol Bantuan yang berisi informasi penggunaan aplikasi, dan tombol Tentang yang berisi informasi pembuat aplikasi. Tampilan awal aplikasi ditunjukkan oleh Gambar 20.

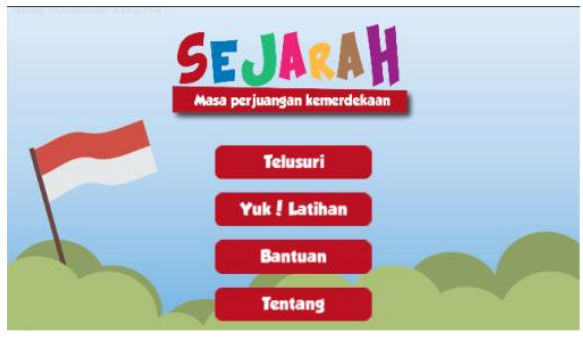

Gambar 20.Tampilan awal aplikasi

\section{Menu Telusuri}

Menu Telusuri merupakan bagian inti dari aplikasi ini. Ketika menu Telusuri dipilih, akan ditampilkan Peta Indonesia beserta tombol-tombol di dalam peta berupa ikon atau foto yang dapat dipilih atau ditekan. Selain itu terdapat opsi Daftar Isi di mana pengguna dapat melihat daftar materi dalam bentuk yang terurut. Tampilan menu Telusuri apabila ditekan, ditunjukkan oleh Gambar 21 dan 22.

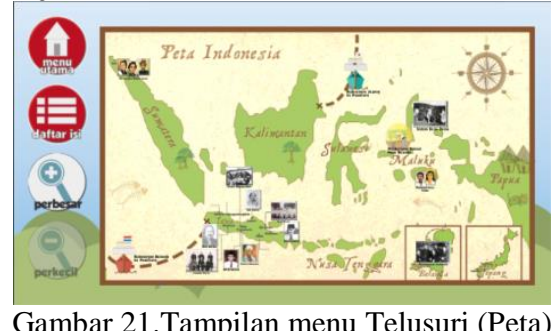

(Peta)

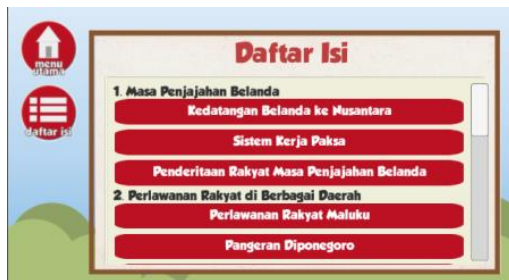

Gambar 22.Tampilan menu Telusuri (Daftar Isi)

Tombol-tombol tersebut mewakili suatu materi dan diletakkan berdasarkan informasi tempat peristiwa tersebut terjadi. Tampilan menu materi ditunjukkan oleh Gambar 23.

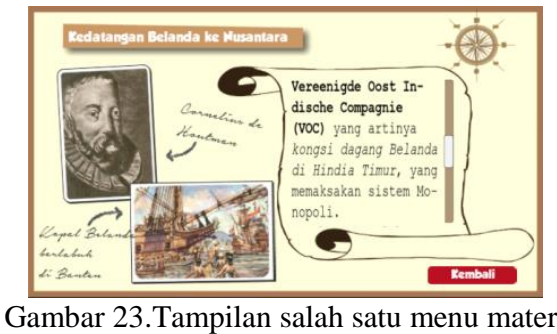

\section{Menu Yuk Latihan}

Menu Yuk Latihan pada aplikasi ini berisi soal-soal yang berasal dari materi yang tersedia. Jumlah soal sebanyak 30 soal. Menu ini bertujuan untuk menguji pengetahuan siswa mengenai materi yang telah disediakan. Terdapat 3 bentuk soal, yaitu pilihan ganda, tebak gambar, dan mencari kota atau daerah di peta. Dalam satu soal memiliki 1 atau 2 jawaban. Jika jawaban telah dipilih, salah maupun benar maka soal akan berpindah ke soal selanjutnya. Jika jawaban benar, maka akan muncul tanda berbentuk lingkaran. Sedangkan jika salah akan muncul tanda berbentuk silang. Hasil nilai sementara ditampilkan disudut kanan atas halaman. Setelah selesai menjawab semua soal, maka akan ditampilkan nilai hasil dari latihan. Tampilan menu Yuk Latihan apabila ditekan, ditunjukkan oleh Gambar 24 sampai 26.

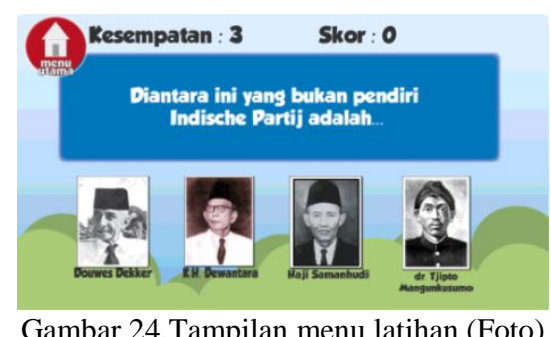

Gambar 24.Tampilan menu latihan (Foto) 

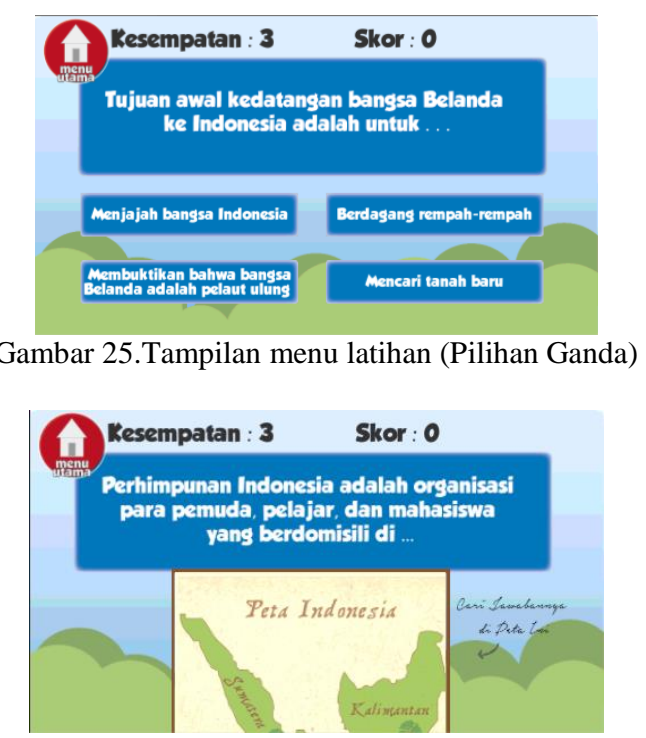

Gambar 26.Tampilan menu latihan (Peta)

\section{Menu Bantuan}

Menu Bantuan pada aplikasi ini berisi mengenai informasi dan kegunaan dari tiap menu yang disediakan di halaman utama. Tampilan menu Bantuan apabila ditekan, ditunjukkan oleh Gambar 27.

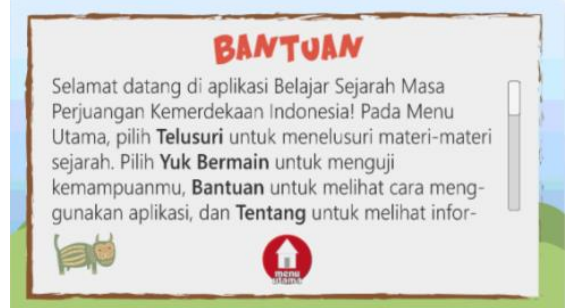

Gambar 27.Tampilan isi menu Bantuan

\section{Menu Tentang Saya}

Menu Tentang Saya pada aplikasi ini berisi mengenai informasi yang berkaitan dengan pembuatan aplikasi multimedia pembelajaran ini. Tampilan menu Tentang Saya apabila ditekan, ditunjukkan oleh Gambar 28.

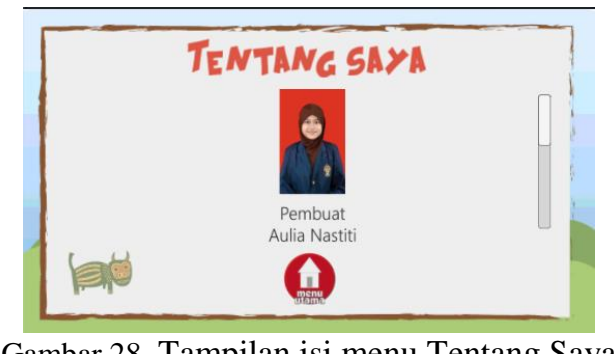

Gambar 28. Tampilan isi menu Tentang Saya

B. Pengujian aplikasi menggunakan metode black-box

Pengujian aplikasi multimedia pembelajaran interaktif ini dilakukan dengan menggunakan metode uji kotak hitam. Pengujian ini dilakukan untuk menunjukkan fungsi program yang dibuat tentang cara operasi dan kegunaannya, apakah keluaran data sesuai dengan yang diharapkan. Pengujian ini dilakukan untuk mengetahui apakah masih terjadi kesalahan program atau program sudah berhasil diselesaikan dengan benar..

Pengujian aplikasi dibuat berupa tabel - tabel pengujian black-box dari masing-masing menu yang ada dalam aplikasi. Tabel pengujian aplikasi secara keseluruhan ditunjukkan oleh Tabel 10

Tabel 10 Tabel pengujian aplikasi secara keseluruhan

\begin{tabular}{|c|c|c|c|}
\hline $\begin{array}{c}\text { Nama } \\
\text { Pengujian }\end{array}$ & $\begin{array}{c}\text { Bentuk } \\
\text { Pengujian }\end{array}$ & Hasil yang Diharapkan & $\begin{array}{c}\text { Hasil } \\
\text { Pengujian }\end{array}$ \\
\hline $\begin{array}{l}\text { Loading } \\
\text { (memuat } \\
\text { data) }\end{array}$ & $\begin{array}{l}\text { Membuka } \\
\text { aplikasi }\end{array}$ & $\begin{array}{l}\text { Tampilan halaman } \\
\text { utama }\end{array}$ & Berhasil \\
\hline $\begin{array}{l}\text { Pengujian } \\
\text { menu } \\
\text { Telusuri }\end{array}$ & $\begin{array}{l}\text { Mengklik } \\
\text { tombol } \\
\text { Mulai }\end{array}$ & $\begin{array}{l}\text { Tampil Peta } \\
\text { Indonesia beserta } \\
\text { tombol berupa ikon } \\
\text { materi }\end{array}$ & Berhasil \\
\hline $\begin{array}{l}\text { Pengujian } \\
\text { menu } \\
\text { Latihan }\end{array}$ & $\begin{array}{l}\text { Mengklik } \\
\text { tombol } \\
\text { Latihan }\end{array}$ & $\begin{array}{l}\text { Tampil halaman } \\
\text { cara mengerjakan } \\
\text { soal }\end{array}$ & Berhasil \\
\hline $\begin{array}{l}\text { Pengujian } \\
\text { menu } \\
\text { Bantuan }\end{array}$ & $\begin{array}{l}\text { Mengklik } \\
\text { tombol } \\
\text { Bantuan }\end{array}$ & $\begin{array}{l}\text { Tampil halaman } \\
\text { informasi } \\
\text { penggunaan aplikasi }\end{array}$ & Berhasil \\
\hline $\begin{array}{l}\text { Pengujian } \\
\text { menu } \\
\text { Tentang }\end{array}$ & $\begin{array}{l}\text { Mengklik } \\
\text { tombol } \\
\text { Tentang } \\
\end{array}$ & $\begin{array}{l}\text { Tampil halaman } \\
\text { informasi mengenai } \\
\text { pembuat aplikasi }\end{array}$ & Berhasil \\
\hline $\begin{array}{l}\text { Pengujian } \\
\text { menu } \\
\text { selanjutnya }\end{array}$ & $\begin{array}{l}\text { Mengklik } \\
\text { tombol } \\
\text { Selanjutnya }\end{array}$ & $\begin{array}{l}\text { Tampil halaman } \\
\text { cara mengerjakan } \\
\text { soal selanjutnya }\end{array}$ & Berhasil \\
\hline $\begin{array}{l}\text { Pengujian } \\
\text { menu } \\
\text { sebelumnya }\end{array}$ & $\begin{array}{l}\text { Mengklik } \\
\text { tombol } \\
\text { Sebelumnya }\end{array}$ & $\begin{array}{l}\text { Tampil halaman } \\
\text { cara mengerjakan } \\
\text { soal sebelumnya }\end{array}$ & Berhasil \\
\hline
\end{tabular}

C. Analisis hasil pengujian aplikasi menggunakan kuisioner

Pengujian aplikasi ini ditargetkan kepada siswa sekolah dasar kelas V. Pengujian aplikasi ini dilakukan dengan cara menjelaskan aplikasi kepada siswa, membimbing siswa dalam menggunakan aplikasi dan meminta siswa untuk menelusuri sendiri aplikasi ini. Siswa juga dapat memasang aplikasi ini di ponsel pribadi. Setelah siswa selesai menelusuri fitur-fitur yang terdapat di dalam aplikasi kemudian diberikan kuesioner yang berisi pertanyaan yang berkaitan dengan aplikasi tersebut. Terdapat sejumlah 20 kuesioner yang dibagikan kepada siswa. Kuisioner tersebut akan digunakan untuk mendapatkan data yang nantinya akan diolah dan dianalisa. Kuesioner yang dibagikan berisi 10 pertanyaan yang harus diisi dengan pilihan jawaban berupa pendapat Sangat Setuju (SS), Setuju (S), Kurang Setuju (KS) dan Tidak Setuju (TS). Data diolah dan disajikan dalam bentuk tabel. Untuk mencari nilai presentase dari masingmasing jawaban kuesioner, digunakan rumus skala Likert sebagai berikut :

$$
\mathrm{P}(\mathrm{S})=\frac{S}{N} \times 100 \%
$$

$\mathrm{P}(\mathrm{S})=$ Presentase sub variabel

$\mathrm{S}=$ jumlah skor tiap sub variabel

$\mathrm{N}=$ jumlah skor maksimum

Berikut adalah hasil persentase masing-masing jawaban dari sepuluh soal yang kemudian dihitung nilainya dengan menggunakan rumus (2.1). 
1. Hasil pengujian pertanyaan nomor 1 ditunjukkan pada Tabel 11.

Tabel 11 Tabel kuesioner pertanyaan nomor 1

\begin{tabular}{|c|c|c|c|c|}
\hline Pertanyaan & Keterangan & Skor & Responden & $\begin{array}{c}\text { Skor x } \\
\text { Responden }\end{array}$ \\
\hline \multirow{3}{*}{1} & SS & 4 & 10 & 40 \\
\cline { 2 - 5 } & S & 3 & 9 & 27 \\
\cline { 2 - 5 } & KS & 2 & 0 & 0 \\
\cline { 2 - 5 } & TS & 1 & 1 & 1 \\
\hline \multicolumn{2}{|c|}{ Jumlah } & 20 & 68 \\
\hline
\end{tabular}

$$
P(S)=\frac{68}{80} \times 100 \%=85 \%
$$

2. Hasil pengujian pertanyaan nomor 2 ditunjukkan pada Tabel 12.

Tabel 12 Tabel kuesioner pertanyaan nomor 2

\begin{tabular}{|c|c|c|c|c|}
\hline Pertanyaan & Keterangan & Skor & Responden & $\begin{array}{c}\text { Skor x } \\
\text { Responden }\end{array}$ \\
\hline \multirow{3}{*}{2} & SS & 4 & 8 & 32 \\
\cline { 2 - 5 } & S & 3 & 12 & 36 \\
\cline { 2 - 5 } & KS & 2 & 0 & 0 \\
\cline { 2 - 5 } & TS & 1 & 0 & 0 \\
\hline \multicolumn{3}{|c|}{ Jumlah } & 20 & 68 \\
\hline
\end{tabular}

$$
P(S)=\frac{68}{80} \times 100 \%=85 \%
$$

3. Hasil pengujian pertanyaan nomor 3 ditunjukkan pada Tabel 13.

Tabel 13 Tabel kuesioner pertanyaan nomor 3

\begin{tabular}{|c|c|c|c|c|}
\hline Pertanyaan & Keterangan & Skor & Responden & $\begin{array}{c}\text { Skor x } \\
\text { Responden }\end{array}$ \\
\hline \multirow{3}{*}{3} & SS & 4 & 8 & 32 \\
\cline { 2 - 5 } & S & 3 & 10 & 30 \\
\cline { 2 - 5 } & KS & 2 & 2 & 4 \\
\cline { 2 - 5 } & TS & 1 & 0 & 0 \\
\hline \multicolumn{2}{|l}{ Jumlah } & 20 & 66 \\
\hline
\end{tabular}

$$
P(S)=\frac{66}{80} \times 100 \%=82,5 \%
$$

4. Hasil pengujian pertanyaan nomor 4 ditunjukkan pada Tabel 14.

Tabel 14 Tabel kuesioner pertanyaan nomor 4

\begin{tabular}{|c|c|c|c|c|}
\hline Pertanyaan & Keterangan & Skor & Responden & $\begin{array}{c}\text { Skor x } \\
\text { Responden }\end{array}$ \\
\hline \multirow{3}{*}{4} & SS & 4 & 8 & 32 \\
\cline { 2 - 5 } & S & 3 & 12 & 36 \\
\cline { 2 - 5 } & KS & 2 & 0 & 0 \\
\cline { 2 - 5 } & TS & 1 & 0 & 0 \\
\hline \multicolumn{3}{|c|}{ Jumlah } & 20 & 68 \\
\hline
\end{tabular}

$$
P(S)=\frac{68}{80} \times 100 \%=85 \%
$$

5. Hasil pengujian pertanyaan nomor 5 ditunjukkan pada Tabel 15.

Tabel 15 Tabel kuesioner pertanyaan nomor 5

\begin{tabular}{|c|c|c|c|c|}
\hline Pertanyaan & Keterangan & Skor & Responden & $\begin{array}{c}\text { Skor x } \\
\text { Responden }\end{array}$ \\
\hline \multirow{3}{*}{5} & SS & 4 & 5 & 20 \\
\cline { 2 - 5 } & S & 3 & 13 & 39 \\
\cline { 2 - 5 } & KS & 2 & 2 & 4 \\
\cline { 2 - 5 } & TS & 1 & 0 & 0 \\
\hline \multicolumn{2}{|c}{ Jumlah } & 20 & 63 \\
\hline
\end{tabular}

$$
P(S)=\frac{63}{80} \times 100 \%=78,75 \%
$$

6. Hasil pengujian pertanyaan nomor 6 ditunjukkan pada Tabel 16.

Tabel 16 Tabel kuesioner pertanyaan nomor 6

\begin{tabular}{|c|c|c|c|c|}
\hline Pertanyaan & Keterangan & Skor & Responden & $\begin{array}{c}\text { Skor x } \\
\text { Responden }\end{array}$ \\
\hline \multirow{4}{*}{6} & SS & 4 & 11 & 44 \\
\cline { 2 - 5 } & S & 3 & 9 & 27 \\
\cline { 2 - 5 } & KS & 2 & 0 & 0 \\
\cline { 2 - 5 } & TS & 1 & 0 & 0 \\
\hline \multicolumn{2}{|l}{ Jumlah } & 20 & 71 \\
\hline
\end{tabular}

$$
P(S)=\frac{71}{80} \times 100 \%=88,75 \%
$$

7. Hasil pengujian pertanyaan nomor 7 ditunjukkan pada Tabel 17.

Tabel 17 Tabel kuesioner pertanyaan nomor 7

\begin{tabular}{|c|c|c|c|c|}
\hline Pertanyaan & Keterangan & Skor & Responden & $\begin{array}{c}\text { Skor x } \\
\text { Responden }\end{array}$ \\
\hline \multirow{4}{*}{7} & SS & 4 & 10 & 40 \\
\cline { 2 - 5 } & S & 3 & 10 & 30 \\
\cline { 2 - 5 } & KS & 2 & 0 & 2 \\
\cline { 2 - 5 } & TS & 1 & 0 & 0 \\
\hline \multicolumn{3}{|c|}{ Jumlah } & 20 & 70 \\
\hline
\end{tabular}

$$
P(S)=\frac{70}{80} \times 100 \%=87,5 \%
$$

8. Hasil pengujian pertanyaan nomor 8 ditunjukkan pada Tabel 18.

Tabel 18 Tabel kuesioner pertanyaan nomor 8

\begin{tabular}{|c|c|c|c|c|}
\hline Pertanyaan & Keterangan & Skor & Responden & $\begin{array}{c}\text { Skor x } \\
\text { Responden }\end{array}$ \\
\hline \multirow{3}{*}{8} & SS & 4 & 10 & 40 \\
\cline { 2 - 5 } & S & 3 & 8 & 24 \\
\cline { 2 - 5 } & KS & 2 & 1 & 2 \\
\cline { 2 - 5 } & TS & 1 & 1 & 1 \\
\hline \multicolumn{3}{|c}{ Jumlah } & 20 & 67 \\
\hline
\end{tabular}

$$
P(S)=\frac{67}{80} \times 100 \%=83,75 \%
$$


9. Hasil pengujian pertanyaan nomor 9 ditunjukkan pada Tabel 19.

Tabel 19 Tabel kuesioner pertanyaan nomor 9

\begin{tabular}{|c|c|c|c|c|}
\hline Pertanyaan & Keterangan & Skor & Responden & $\begin{array}{c}\text { Skor x } \\
\text { Responden }\end{array}$ \\
\hline \multirow{3}{*}{9} & SS & 4 & 4 & 16 \\
\cline { 2 - 5 } & S & 3 & 16 & 48 \\
\cline { 2 - 5 } & KS & 2 & 0 & 0 \\
\cline { 2 - 5 } & TS & 1 & 0 & 0 \\
\hline \multicolumn{3}{|c}{ Jumlah } & 20 & 64 \\
\hline
\end{tabular}

$$
P(S)=\frac{64}{80} \times 100 \%=80 \%
$$

10. Hasil pengujian pertanyaan nomor 10 ditunjukkan pada Tabel 20 .

Tabel 20 Tabel kuesioner pertanyaan nomor 10

\begin{tabular}{|c|c|c|c|c|}
\hline Pertanyaan & Keterangan & Skor & Responden & $\begin{array}{c}\text { Skor x } \\
\text { Responden }\end{array}$ \\
\hline \multirow{3}{*}{10} & SS & 4 & 9 & 36 \\
\cline { 2 - 5 } & S & 3 & 10 & 30 \\
\cline { 2 - 5 } & KS & 2 & 1 & 2 \\
\cline { 2 - 5 } & TS & 1 & 0 & 0 \\
\hline \multicolumn{2}{|c}{ Jumlah } & 20 & 68 \\
\hline
\end{tabular}

$$
P(S)=\frac{68}{80} \times 100 \%=85 \%
$$

Interval Penilaian :

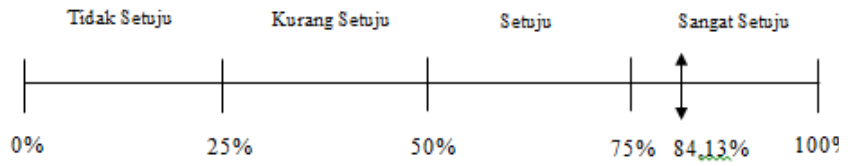

\section{Pembahasan}

Hasil pengujian aplikasi menggunakan metode uji kotak hitam (black-box testing) menunjukkan bahwa fungsi pada aplikasi telah berjalan sesuai dengan yang diharapkan. Hal ini ditampilkan oleh tabel 4.1 hingga tabel 4.4 yang menunjukkan hasil uji "Berhasil" pada tiap fungsi dan tombol dari aplikasi. Hal ini berarti bahwa secara fungsional, aplikasi ini telah berfungsi dengan baik. Berdasarkan interval penilaian persentase responden yaitu $84,13 \%$ dapat disimpulkan bahwa responden memberikan respon positif terhadap aplikasi yang berarti juga lebih dari $75 \%$ menjawab Setuju (S) dan Sangat Setuju (SS) dengan tujuan perancangan aplikasi multimedia pendamping pembelajaran Sejarah ini.

\section{E. Distribusi}

Hasil aplikasi dapat didistribusikan ke smartphone pengguna melalui kabel data. Selain itu pendistribusian aplikasi ini juga dilakukan dengan mem-publish aplikasi tersebut ke PlayStore. Tujuan dari pendistribusian aplikasi ini selain untuk menyebarkan aplikasi pendamping pembelajaran melalui jaringan juga untuk dapat menjadi sebuah evaluasi sehingga akan dapat mengembangkan sistem menjadi lebih baik lagi.

\section{PENUTUP}

A. Kesimpulan

Kesimpulan dari penelitian Tugas Akhir ini diantaranya sebagai berikut.

1. Aplikasi yang dibuat merupakan aplikasi media pembelajaran yang berisi materi sejarah masa perjuangan kemerdekaan beserta peta alokasi kejadiankejadian sejarah beserta soal-soal latihan untuk menguji kemampuan siswa, ditujukan untuk pengguna yang bersekolah di kelas 5 Sekolah Dasar, dan dibuat menggunakan Unity Engine 5 dan Adobe Illustrator CS6.

2. Berdasarkan hasil pengujian aplikasi menggunakan Uji Kotak Hitam (Black Box Test), seluruh fungsi menu yang ada dalam aplikasi telah berhasil sesuai dengan fungsinya.

3. Berdasarkan hasil olahan data kuesioner menunjukkan bahwa $75 \%$ lebih jawaban positif, artinya lebih dari $75 \%$ menjawab Setuju (S) dan Sangat Setuju (SS) pada pertanyaan kuesioner. Rata-rata skor dari seluruh hasil kuesioner adalah 84,13 atau termasuk dalam kategori "Baik". Hal ini berarti aplikasi telah berjalan dengan baik dan dapat direkomendasikan sebagai Aplikasi Pembelajaran Sejarah Masa Perjuangan Kemerdekaan untuk Sekolah Dasar.

B. Saran

Saran yang dapat dapat digunakan untuk penelitian lebih lanjut adalah sebagai berikut.

1. Aplikasi media pembelajaran yang dibuat adalah untuk materi Sejarah Masa Perjuangan Kemerdekaan yang diambil dari buku Ilmu Pengetahuan Sosial untuk kelas 5 Sekolah Dasar dan dapat dikembangkan menjadi aplikasi belajar Sejarah secara umum.

2. Aplikasi media pembalajaran dapat diberi tambahan berupa animasi dalam setiap materi untuk lebih meningkatkan minat siswa dalam mempelajari sejarah.

\section{DAFTAR PUSTAKA}

[1] A. Achsin, Media Pendidikan dalam Kegiatan Belajar Mengajar, Ujung Pandang: Penerbit IKIP Ujung Pandang, 1986.

[2] M. Suyanto, Aplikasi Desain Grafis Untuk Periklanan, Yogyakarta: Andi, 2004

[3] R. E. Mayer, Multimedia Learning, Yogyakarta: Pustaka Pelajar, 2009, pp. 1-4

[4] S. Nandi, "Penggunaan Multimedia Interaktif dalam Pembelajaran Geografi di Persekolahan," Jurnal "GEA" Jurusan Pendidikan Geografi Vol.6, No.1, 2006.

[5] P. Indriani and S. Rochmat, Ilmu Pengetahuan Sosial Kelas 5 SD, Bogor: Yudhistira, 2008

[6] B. Sihite, F. Samopa and N. A. Sani, "Pembuatan Aplikasi 3D Viewer Mobile dengan Menggunakan Teknologi Virtual Reality (Studi Kasus: Perobekan Bendara Belanda di Hotel Majapahit)," Jurnal Teknik POMITS Vol.2, No.2, 2013

[7] I. Binanto, Multimedia Digital-Dasar Teori dan Pengembangannya, Yogyakarta: C.V. ANDI OFFSET, 2010

[8] R. Caterin, Aplikasi Multimedia Dalam Pembelajaran Teknologi Informasi dan Komunikasi (TIK) Mater Hardware Berbasis Flash Untuk Sekolah Menengah Atas. Tugas Akhir pada Prodi Sistem Komputer FT UNDIP, Semarang: tidak diterbitkan, 2014. 
